\title{
Analysis of Using Calcium Hydroxide to Disinfect Animal Farm and Eradicate Harmful Pathogens
}

\author{
Dae-yeong Park1), Jong-chun Kim²), Dong-hyun Kim³), Won-sik Choi4)
}

\begin{abstract}
In intensive animal farming, which is preferred for economic reasons, a single case of infection of contagious diseases like swine fever requires massive culling of livestock on the farm or on the premises and distant farms as well. This study aimed to disinfect organic pathogens and harmful bacteria on the farm and to prevent seasonal contagious diseases. It also analyzed harmful pathogens that arose from corrosion in groundwater supply in order to boost immune system of animals. Based on the findings, disinfection of harmful pathogens on the farm decreased the resistance of microorganisms. This study drew the result of creating prevention for contagious diseases like swine fever just in short time by improving the immune system of the livestock to the harmful pathogen and bacteria through sterilizing the animal farm with calcium hydroxide.
\end{abstract}

Keywords: Pigsty, Microorganism, Calcium Hydroxide, Swine Fever, Disinfection

\section{Introduction}

As intensive animal farming has become a preferred type of animal husbandry for economic reasons across the world, a single case of infection of contagious diseases like swine fever requires massive to culling of the whole or of livestock from the premises and distant farms. An outbreak of swine fever, in particular, affects economy of a country greatly because it demands to cull of livestock and preventive intervention costs such as for vaccination. It also leads to decline in production and international trade restrictions of livestock and animal products. The study is aimed to prevent the farm from seasonal contagious infections by

Received(December 10, 2019), Review Result(1st: January 10, 2020, 2nd: February 28, 2020), Accepted(April 25, 2020)

1) (Professor) 50463 Dept. Bio Industrial Machinery Engineering, Pusan National University, Miryang, Korea email: dypark@pusan.ac.kr

2) (CEO) 52015 Yuseong-ro, Chilseo-myeon, Haman-gun, Korea

email: konegood@nate.com

3) (CTO) 52015 Yuseong-ro, Chilseo-myeon, Haman-gun, Korea

email: jookgasem@nate.com

4) (Professor, Corresponding Author) 50463 Dept. Bio Industrial Machinery Engineering, Pusan National University, Miryang, Korea

email: choi@pusan.ac.kr 
disinfecting organic pathogens and harmful bacterias as preventive measures and to boost animal immune system by analyzing the effectiveness of improving livestock breeding environment and by analyzing harmful pathogens arising from corrosion of groundwater which is the source of water supply on the farm. The experiments such as disinfection of harmful pathogens, sampling of various harmful microbes in the farm surroundings and soil, and improvements of breeding environment, were done in a pig farm in Miryang City and a pig farm in Haman county. Regarding conventional ways of farming, new issues such as prevention measures and animal welfare caused by massive culling have came about due to spending over the national budget. But, the study analyzed the effectiveness of calcium hydroxide for animal farming purpose in suppressing the growth of pathogens, airborne bacterias and fungi when used in a regular basis and experimented on the corrosion of water pipes that supply water in the farms. Since integrity of breeding environment may affect both livestock industry and health of the workers, it has become important to manage harmful factors in order to promote eco-friendly farming and to secure health welfare of the workers. There are not many studies done on the effects of eradicating microorganisms that transmit various pathogens on the health of livestock in respect to contagious infections. Hence, in order to investigate the effects of quicklime on harmful microbes and corrosion, this study took 5 weeks to analyze harmful pathogens in the farm, to experiment on the corrosion of water pipes that supply water in the farm. The results were examined and interpreted after the experiments have completed.

\section{Review of Literature}

Disinfection is related to not doing direct damage to pathogenic microorganisms. It is being used interchangeably with sterilization, and the terms should be differentiated by the process of decontamination of pathogenic microorganisms contaminated by a substance or a container. Sterilization is the process of killing all microbes found on a substance, and disinfection is the process of decontaminating pathogenic microorganisms for a specific purpose. Disinfection is a method of preventing damages against contagious infections by eliminating infectious pathogens and microorganisms that transmit the former. Also it is one important way of preventing outbreak or spread of contagious animal diseases. When a disinfectant is used, it should be used under favorable conditions. The ideal conditions of disinfectant are strong effect with minimal use, soluble in water, long preservation period and less toxicity. In order to disinfect a large-scale farm, the entity being disinfected should not be damaged in the process[1]. Since 
bacteria or virus takes about 2 weeks to return to its normal state after disinfection, it is appropriate to disinfect the farm after 10 to 14 days, but experiments were done every 7 days. Meanwhile, the factors that affect the corrosion of metal materials in the farm are physical factors such as metal type and temperature of a material, chemical factors such as $\mathrm{pH}$, alkalinity, total dissolved solids (TDS), solidity, dissolved oxygen, residual chlorine, sulfate ion and buffer intensity, and biological factors such as existence of microorganisms[2]. Langelier Saturation Index (LI) indicates possibility of calcium carbonate precipitation in water and it is expressed in Formula (1). When LI is more than 0 calcium carbonate precipitation occurs, and when LI is lower than 0 calcium carbonate is dissolved. Thus, actual LI and corrosion of farm establishments show constant correlation and it is expressed in [Table 1][3].

$$
\begin{aligned}
& \mathrm{LI}=\mathrm{pH}-\mathrm{pHs}-\mathrm{p} \text { - Formula } \\
& \mathrm{pHs}=\mathrm{A}+\mathrm{B}-\log [\mathrm{Ca}]-\log [\text { alkalinity }]
\end{aligned}
$$

[Table 1] Corrosion Characteristics vs. LI(Kawamura, 2000)

\begin{tabular}{|c|c|}
\hline Classification & LI \\
\hline Medium to heavy scaling & $+0.5 \sim+1.0$ \\
\hline Slight scale formation & $+0.2 \sim+0.3$ \\
\hline Equilibrium & 0 \\
\hline Slightly corrosive & $-0.2 \sim-0.3$ \\
\hline Medium to heavy corrosion & $-0.5 \sim-1.0$ \\
\hline
\end{tabular}

In the equation, $\mathrm{pH}$ is value of actual measurement, and $\mathrm{pHs}$ is $\mathrm{pH}$ value when calcium carbonate is saturated. A and B are water temperature and TDS related value respectively, and calcium and alkalinity are expressed in concentration of $\mathrm{CaCO} 3(\mathrm{mg} / \mathrm{L}) .20 \%$ calcium hydroxide safe for farm use was used in the experiment, and liquid carbon dioxide was dissolved in distilled water and adjusted its $\mathrm{pH}$ to 3.91 for carbon dioxide injection experiment. On the other hand, most pathogens are usually found with organic matters like animal excrement and urine which may make disinfection less effective. Pens were cleaned thoroughly by pressure washer or detergent (surfactant) in order to remove organic matters before disinfecting with calcium hydroxide. Glutaraldehyde is used in 1-2\% concentration that is effective as disinfectant even in presence of organic matters. The cost is high for a large scale use, but formalin $(40 \%$ formaldehyde solution) has similar effectiveness with glutaraldehyde when $8 \%$ concentration is used[4]. 


\subsection{Stabilization of Animal Farming Environment Using Calcium Hydroxide}

\subsubsection{Ion-exchange Reaction}

Ion-exchange reaction is a reaction in which $\mathrm{Ca}^{2^{+}}$replaces $\mathrm{Na}^{+}, \mathrm{K}^{+}, \mathrm{H}^{+}, \mathrm{Mg}^{2^{+}}$that are held on the surface when calcium ion of lime reacts with particles in water. When $\mathrm{Ca}(\mathrm{OH})_{2}$ reacts beyond ion-exchange capacity, $\mathrm{OH}^{-}$is increased and massive absorption occurs. This is called affinity which means ion-exchange takes place when affinity of $\mathrm{Ca}^{2^{+}}$is higher than $\mathrm{Na}^{+}, \mathrm{K}^{+}$, $\mathrm{H}^{+}, \mathrm{Mg}^{2^{+}}$. Order of affinity is as follows[5]: $\mathrm{Li}^{+}<\mathrm{Na}^{+}<\mathrm{H}^{+}<\mathrm{K}^{+}<\mathrm{Mg}^{2^{+}}<\mathrm{Ca}^{2^{+}}<$ $\mathrm{Ai}^{3^{+}}$When $\mathrm{Ca}(\mathrm{OH})_{2}$ reacts beyond ion-exchange capacity, $\mathrm{OH}^{-}$is increased making the water alkaline, and $\mathrm{Ca}^{2^{+}}$is absorbed massively. Soil particles and fine particles that resisted each other are bonded into a large mass, and this is called "unification"[6].

\subsubsection{Pozzolanic Reaction}

Fine powder with highly active amorphous silica, in presence of moisture, reacts with $\mathrm{Ca}(\mathrm{OH})_{2}$ at room temperature to form silica properties is called Pozzolanic reaction. Pozzola has various compositions among which commonly known are $\mathrm{S}_{i} \mathrm{O}_{2}$ and $\mathrm{Ai}_{2} \mathrm{O}_{3}$. It reacts with calcium hydroxide created during hydration reaction to increase C-S-H substance that intensifies cement, and alumina creates C-A-H.

In the eradication and prevention of putrefaction of harmful pathogens, calcium hydroxide suppresses the growth of microorganisms due to high $\mathrm{pH}$ level and exothermic reaction that occurs during hydrothermic reaction and, in consequence, the putrefaction rate of organic matter decreases.

Normally when pH 12 or above is maintained, activity of partial pathogens is suppressed. [Table 2] below shows that Pseudomonas Aeruginosa, Salmonella and others have been eradicated after lime stabilization with results below detection level.

[Table 2] Research on Quicklime Stabilization of Sludge (Lue-ng, Ce tal , 19 90)

\begin{tabular}{|c|c|c|c|c|c|}
\hline \multirow{2}{*}{$\begin{array}{c}\text { Forms of } \\
\text { Sludge }\end{array}$} & \multicolumn{5}{|c|}{ Bacteria Density, Bacteria Number/100ml } \\
\cline { 2 - 6 } & $\begin{array}{c}\text { Total } \\
\text { Coliforms }\end{array}$ & $\begin{array}{c}\text { Fecal } \\
\text { Coliforms }\end{array}$ & $\begin{array}{c}\text { Fecal } \\
\text { Stretococci }\end{array}$ & Salmonella & $\begin{array}{c}\text { Pseudomonas } \\
\text { Aeruginosa }\end{array}$ \\
\hline
\end{tabular}

Furthermore, when various kinds of sludge before being solidified after the spray of calcium 
hydroxide in the farm; $\mathrm{H} 2 \mathrm{~S}$ is created from organic matter decomposition of microbes which gives a smell of rotten eggs. By injecting lime, $\mathrm{pH}$ increases to hinder growth of microorganisms stopping organic matter decomposition. As $\mathrm{pH}$ increases to 9 or above, H2S becomes volatile and smell fades away.

\subsection{Langelier Saturation Index (LI)}

Langelier saturation index (LI) was developed by W.F. Langelier in 1936 as an indicator to determine the tendency of calcium carbonate $(\mathrm{CaCO})$ to form scale in water. LI uses correlation of water $\mathrm{pH}$ and alkalinity and $\mathrm{pHs}$ to estimate whether calcium carbonate precipitation occurs in thin layer to form scale in the tube. If calcium carbonate scale is formed in the inner wall of water pipes, it can act as corrosion resistant layer to suppress corrosion caused by tap water on the surface of water pipes[7].

Saturation index of calcium carbonate is calculated as Formula 1[8].

$$
\mathrm{LI}=\mathrm{pH}-\mathrm{pHs}
$$

$\mathrm{pH}=$ measured value $\mathrm{pHs}=\mathrm{pH}$ value of $\mathrm{CaCO} 3$ in equilibrium in presence of calcium ion and bicarbonate ions pHs is calculated as Formula 2.

$$
\mathrm{pHs}=\mathrm{pK} 2-\mathrm{pKs}+\mathrm{p}[\mathrm{Ca} 2+]+\mathrm{p}[\mathrm{HCO} 3-]+5 \mathrm{pfm}
$$

(Fomula 2)

\section{Methodology}

This study was experimented in the farms located in Miryang City and Haman county in order to disinfect the farms and soil using calcium hydroxide for its purpose and water $\left(300-400 \mathrm{~g}\right.$ per $\left.1 \mathrm{~m}^{2}\right)$. It also examined corrosion of groundwater that is source of water supply in the farms.

\subsection{Changes in Microorganisms before and after Calcium Hydroxide Disinfection}

Preliminary disinfection for experiments takes place in the morning of a clear day. Alkaline aqueous solution of $3 \ell$ per $1 \mathrm{~m}^{2}$ (enough to soak $3 \mathrm{~mm}$ high) and disinfectant of $2 \ell$ per $1 \mathrm{~m}^{2}$ (enough to soak $2 \mathrm{~mm}$ high) are prepared to clean the farm by spraying them adequately. In presence of rice hulls, excrement and others in the farm, fermentation method of disinfection should be carried out before a hole 1-2 meters wide and 20 centimeters deep is digged. After 
scattering slaked lime in the hole, pile of excrement, straws and others are added 1-2 meters high, and soil or plastics are used to cover up the hole to prevent contact from outside for about 2 weeks. Fermentation temperature of $60-70^{\circ} \mathrm{C}$ is maintained for several days. Sampling is extracted from the solution flowing down from ground in a beaker on a weekly basis and used to analyze strain and number of microorganisms with a high-resolution microscope. Results should be analyzed.

\subsection{Changes in Corrosive Index Using Calcium Hydroxide}

Water supply in the farm as experimental sample is an undiluted solution. $25 \%$ calcium hydroxide was diluted in water to make $100 \mathrm{mg} / \mathrm{L}$ solution which was distributed in amounts of $5 \mathrm{mg} / \mathrm{L}, 10 \mathrm{mg} / \mathrm{L}, 15 \mathrm{mg} / \mathrm{L}, 20 \mathrm{mg} / \mathrm{L}$ in the respective beaker. $1000 \mathrm{~mL}$ of water supply was used in the experiment.

[Table 3] Calcium Concentration of Calcium Hydroxide

\begin{tabular}{|c|c|c|}
\hline $\begin{array}{c}25 \% \text { calcium hydroxide } \\
\text { diluted solution }(\mathrm{mg} / \mathrm{L})\end{array}$ & $\begin{array}{c}\text { calcium hydroxide injection } \\
(\mathrm{mL})\end{array}$ & $\mathrm{Ca} / \mathrm{Ca}(\mathrm{OH}) 2(\mathrm{mg} / \mathrm{L})$ \\
\hline \multirow{3}{*}{100} & 50 & 5 \\
\cline { 2 - 3 } & 100 & 10 \\
\cline { 2 - 3 } & 150 & 15 \\
\cline { 2 - 3 } & 200 & 20 \\
\hline
\end{tabular}

$\mathrm{pH}$ is the most important factor of corrosion. Normally, $\mathrm{pH}$ of water in natural state ranges from $\mathrm{pH} 4.3$ to $\mathrm{pH}$ 10. Speed of corrosion increases in acidic state and decreases in alkaline state. It is suggested to maintain $\mathrm{pH} 6$ or above to prevent corrosion, but when $\mathrm{pH}$ is 8 or above, scale may form from calcium carbonate or calcium phosphate. $\mathrm{pH}$ was measured in accordance to Standard Method of Examination of Water Pollution.

Iron powder (Kanto. Assay $90 \%$ ) was used to observe dissolution testing. As a control group, iron powder of $0.1 \mathrm{~g}$ was mixed to $1000 \mathrm{~mL}$ of tap water from water supply in the farm. $25 \%$ calcium hydroxide was diluted in tap water and adjusted the concentration to $100 \mathrm{mg} / \mathrm{L}$, and this solution was diluted step by step and adjusted to $5 \mathrm{mg} / \mathrm{L}, 10 \mathrm{mg} / \mathrm{L}, 15 \mathrm{mg} / \mathrm{L}, 20 \mathrm{mg} / \mathrm{L}$ concentration respectively. After 0.1 grams of Iron powder was added in each beaker, stirring process of 100 rotations per minute for 24 hours, 48 hours, 72 hours was carried out in jar tester. Concentration of calcium hydroxide is as shown in [Table 4]. 


\begin{tabular}{|c|c|c|}
\hline $\begin{array}{c}25 \% \text { calcium hydroxide diluted solution } \\
\text { concentration } \mathrm{Ca} / \mathrm{Ca}(\mathrm{OH}) 2(\mathrm{mg} / \mathrm{L})\end{array}$ & $\begin{array}{c}\text { calcium hydroxide injection }(\mathrm{mL}) \text { in } \\
1000 \mathrm{~mL} \text { V.F }\end{array}$ & $\begin{array}{c}\mathrm{Ca} / \mathrm{Ca}(\mathrm{OH}) 2 \\
(\mathrm{mg} / \mathrm{L})\end{array}$ \\
\hline \multirow{3}{*}{100} & 50 & 5 \\
\cline { 2 - 3 } & 100 & 10 \\
\cline { 2 - 3 } & 150 & 15 \\
\cline { 2 - 3 } & 200 & 20 \\
\hline
\end{tabular}

\section{Analysis of Data}

\subsection{Changes in Microorganisms before and after Calcium Hydroxide Disinfection}

Comparative analysis of changes in the resistance of microbes suggests decreasing resistance through time as shown in [Table 5] below.

The study categorized pathogenic microorganisms into three groups: strong microbe that has strong resitance, middle microbe that has average resistance, and weak microbe that has less resistance. Strong microbe category includes spore-forming bacterias (Anthrax bacterium, Clostridium chauvoei, Clostridium tetani, Clostridium septicum and more), middle microbe category includes microorganisms (Mycobacterium tuberculosis, Staphylococcus, Streptococcus and more), weak microbe category includes viruses of microorganisms (Escherichia coli, Erysipelothrix rhusiopathiae, Foot-and-mouth disease virus, Swine fever virus, Newcastle disease virus, Rabies virus, Japanese encephalitis virus and more), and the weakest resistance microbes (Haemorrhagic septicaemia bacteria, Brucella bacteria and more) can be easily disinfected by fermentation drying or other methods. The result of the experiment is as shown in [Table 5].

[Table 5] Weekly Changes in the Resistance of Microbes to Calcium Hydroxide Disinfection (C.F.U)

\begin{tabular}{|c|c|c|c|c|c|c|}
\hline Kind & calcium hydroxide & 1week & 2 week & 3 week & 4week & 5week \\
\hline Strong microbe & Approx $3 \ell$ per $1 \mathrm{~m}^{2}$ & 4.3 & 4 & 3.5 & 2.2 & 1.2 \\
\hline middle microbe & Approx $3 \ell$ per $1 \mathrm{~m}^{2}$ & 4.8 & 4.4 & 1.8 & 1 & 0.5 \\
\hline weak microbe & Approx $3 \ell$ per $1 \mathrm{~m}^{2}$ & 3.9 & 3 & 2.1 & 1.3 & 0.2 \\
\hline all average & Approx $3 \ell$ per $1 \mathrm{~m}^{2}$ & 4.3 & 3.8 & 2.46 & 1.4 & 0.5 \\
\hline
\end{tabular}

The resistance of spore-forming bacteria to calcium hydroxide disinfection is $4.3 \mathrm{CFU}$ in week 1. With continuous disinfection in the same amount of calcium hydroxide from week 2, it has decreased from $4.3 \mathrm{CFU}$ in week 1 to $1.2 \mathrm{CFU}$ in week 5. Resistance of medium microbe 
category has decreased from $4.8 \mathrm{CFU}$ in week 1 to $0.5 \mathrm{CFU}$ in week 5, and resistance of weak microbe category has decreased from $3.9 \mathrm{CFU}$ in week 1 to $0.2 \mathrm{CFU}$ in week 5 . Other various microbes are almost hard to find possibly to the extent of eradication. The findings of the experiment are as shown in [Fig. 1] below.

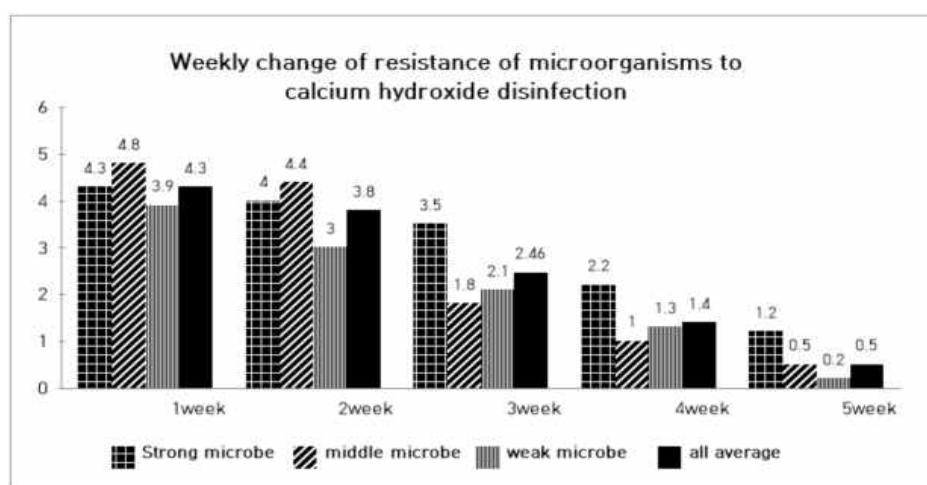

[Fig. 1] Weekly Changes in the Resistance of Microorganisms to Calcium Hydroxide Disinfection

\subsection{Changes in Corrosive Index Using Calcium Hydroxide}

Findings of water supply in the control group farm suggest that LR level has decreased below 0.5. Corrosion in water affected sulfate ions and chlorine ions to react with iron and precipitated as iron sulfate and iron chloride decreasing the ions. calcium hydroxide injection increased alkalinity decreasing LR value as a result. [Table 6] shows changes in corrosive index in respect to slaked lime injection at different time periods.

[Table 6] Measured Data of Corrosive Index in Response to Calcium Hydroxide Injection after 24 hrs, 48 hrs, 72 hrs

\begin{tabular}{|c|c|c|c|c|c|c|c|c|c|c|c|c|}
\hline & $\begin{array}{l}\mathrm{Ti} \\
\mathrm{me}\end{array}$ & $\begin{array}{l}\text { temp } \\
\left({ }^{\circ} \mathrm{C}\right)\end{array}$ & $\mathrm{pH}$ & $\begin{array}{l}\text { Cond } \\
\text { uctivi } \\
\text { ty }(\mu \Omega \\
/ \mathrm{cm})\end{array}$ & $\begin{array}{l}\text { alkalin } \\
\text { ity(mg } \\
\text { /L) }\end{array}$ & $\begin{array}{l}\mathrm{Ca} 2+ \\
(\mathrm{mg} / \mathrm{L} \\
)\end{array}$ & $\begin{array}{l}\mathrm{SO} 42- \\
(\mathrm{mg} / \mathrm{L} \\
)\end{array}$ & $\begin{array}{l}\text { Cl- } \\
(\mathrm{mg} / \\
\mathrm{L})\end{array}$ & LI & RSI & LR & $\mathrm{AI}$ \\
\hline \multirow{3}{*}{$\begin{array}{l}\text { Distill } \\
\text { ed } \\
\text { water }\end{array}$} & 24 & 14.2 & 5.6 & 3 & $<0.01$ & $<0.01$ & $<0.01$ & - & - & - & - & - \\
\hline & 48 & 14.1 & 5.6 & 6 & $0.01<$ & $0.01<$ & $0.01-$ & - & - & - & - & \\
\hline & 72 & 14.1 & 5.8 & 6 & $<0.01$ & $<0.01$ & $<0.01$ & $<-$ & - & - & - & - \\
\hline \multirow{3}{*}{$\begin{array}{l}\mathrm{T} \text { a } \mathrm{p} \\
\text { water }\end{array}$} & 24 & 14.3 & 10.1 & 7.2 & 252 & 45 & 19.1 & 19 & 24.7 & -1.36 & 0.97 & 0.97 \\
\hline & 48 & 14.1 & 7.2 & 243 & 46 & 19.5 & 18 & 24.2 & -1.34 & 9.87 & 0.92 & 10.1 \\
\hline & 72 & 14.1 & 7.3 & 243 & 46 & 19.4 & 18 & 23.7 & -1.24 & 9.77 & 0.91 & 10.25 \\
\hline \multirow{3}{*}{$\begin{array}{l}5 \\
\mathrm{Ca} / \mathrm{Ca} \\
(\mathrm{OH}) 2 \\
\mathrm{mg} / \mathrm{L} \\
\end{array}$} & 24 & 14.2 & 7.7 & 250 & 51 & 20.7 & 18 & 24.1 & -0.77 & 9.2 & 0.83 & 10.7 \\
\hline & 48 & 14.2 & 7.8 & 241 & 48 & 19.5 & 17 & 23.8 & -0.72 & 9.23 & 0.85 & 10.77 \\
\hline & 72 & 14.2 & 7.7 & 261 & 51 & 23.4 & 17 & 23.3 & -0.71 & 9.12 & 0.79 & 10.78 \\
\hline \multirow{2}{*}{$\begin{array}{l}10 \mathrm{Ca} / \\
\mathrm{Ca}(\mathrm{O}\end{array}$} & 24 & 14.3 & 7.9 & 238 & 55 & 21.9 & 18 & 24.5 & -0.51 & 8.9 & 0.77 & 11.0 \\
\hline & 48 & 14.1 & 7.8 & 238 & 56 & 21.6 & 17 & 24.1 & -0.61 & 9.01 & 0.73 & 10.88 \\
\hline
\end{tabular}


Vol.6, No.5, May 31 (2020), pp.111-121

http://dx.doi.org/10.21742/apjcri.2020.05.10

\begin{tabular}{|c|c|c|c|c|c|c|c|c|c|c|c|c|}
\hline $\begin{array}{l}\mathrm{H}) 2 \\
\mathrm{mg} / \mathrm{L}\end{array}$ & 72 & 14.2 & 7.8 & 250 & 7 & 23.9 & 16 & 22.1 & -0.55 & 8.9 & 0.67 & 10.93 \\
\hline \multirow{3}{*}{$\begin{array}{l}1 \quad 5 \\
\mathrm{Ca} / \mathrm{Ca} \\
(\mathrm{OH}) 2 \\
\mathrm{mg} / \mathrm{L}\end{array}$} & 24 & 14.3 & 7.8 & 231 & 66 & 23.6 & 18 & 23.3 & -0.49 & 8.8 & 0.63 & 11. \\
\hline & 48 & 14.2 & 7.8 & 237 & 67 & 24.2 & 16 & 22.8 & -0.47 & 8.75 & 0.58 & 11.1 \\
\hline & 72 & 14.2 & 7.9 & 230 & 66 & 22.4 & 15 & 22.1 & -0.41 & 8.73 & 0.56 & 11.7 \\
\hline \multirow{3}{*}{$\begin{array}{l}2 \quad 0 \\
\mathrm{Ca} / \mathrm{Ca} \\
(\mathrm{OH}) 2 \\
\mathrm{mg} / \mathrm{L}\end{array}$} & 24 & 14.3 & 8.1 & 221 & 70 & 22.9 & 18 & 22.1 & -0.17 & 8.4 & 0.57 & 11.3 \\
\hline & 48 & 14. & 8 & 223 & 71 & 23.8 & 16 & 21 & -0.26 & 8.52 & 20.52 & 11.23 \\
\hline & 72 & 4.2 & 8.1 & 234 & 71 & 24.3 & 14 & 19.2 & -0.15 & 8.41 & 0.47 & 11.34 \\
\hline
\end{tabular}

Corrosion can be determined when Langlier saturated index (LI) is below 0, RSI is 6.8 or above, LR is 0.5 or above, and AI is below 12[9]. When corrosion of tap water in control group was compare with initial measure values, LI, RSI, LR and AI showed no difference in corrosive index at 24-hour, 48-hour and 72-hour time periods.

[Table 7] 24-hour Interval Changes in Iron Concentration in Response to Calcium Hydroxide Injection $(\mathrm{mg} / \mathrm{L})$

\begin{tabular}{|c|c|c|c|c|c|c|}
\hline $\begin{array}{c}\text { Amount } \\
\text { Time }\end{array}$ & $\begin{array}{c}\text { Distilled } \\
\text { water }\end{array}$ & $\begin{array}{c}\text { Tap } \\
\text { water }\end{array}$ & $\begin{array}{c}5 \mathrm{Ca} / \mathrm{Ca}(\mathrm{OH}) 2 \\
\mathrm{mg} / \mathrm{L}\end{array}$ & $\begin{array}{c}10 \mathrm{Ca} / \mathrm{Ca} \\
(\mathrm{OH}) 2 \\
\mathrm{mg} / \mathrm{L}\end{array}$ & $\begin{array}{c}15 \mathrm{Ca} / \mathrm{Ca} \\
(\mathrm{OH}) 2 \\
\mathrm{mg} / \mathrm{L}\end{array}$ & $\begin{array}{c}20 \\
\mathrm{Ca} / \mathrm{Ca}(\mathrm{OH}) 2 \\
\mathrm{mg} / \mathrm{L}\end{array}$ \\
\hline After $24 \mathrm{hrs}$ & 0.109 & 0.155 & 0.135 & 0.112 & 0.079 & 0.056 \\
\hline After $48 \mathrm{hrs}$ & 0.159 & 0.534 & 0.516 & 0.456 & 0.269 & 0.252 \\
\hline After $72 \mathrm{hrs}$ & 0.167 & 0.819 & 0.746 & 0.687 & 0.440 & 0.287 \\
\hline
\end{tabular}

The findings of stirring process of iron of water supply pipes in step by step injection of diluted calcium hydroxide are as follows. Concentration of control group or tap water was $0.155 \mathrm{mg} / \mathrm{L}$ after 24 hours and $0.819 \mathrm{mg} / \mathrm{L}$ after 72 hours which suggests iron concentration has increased by 5.284 times. Iron powder used in the experiment contains $90 \%$ iron which was observed with eyes in iron dissolution process after 20 to 30 minutes. Findings of calcium hydroxide injection from $5 \mathrm{mg} / \mathrm{L}$ to $20 \mathrm{mg} / \mathrm{L}$ after 24 hours show decrease of iron concentration from $0.135 \mathrm{mg} / \mathrm{L}$ to $0.056 \mathrm{mg} / \mathrm{L}$ or from $12.903 \%$ to $63.871 \%$. After 48 hours, iron concentration of tap water is $0.534 \mathrm{mg} / \mathrm{L}$. Findings of calcium hydroxide injection from $5 \mathrm{mg} / \mathrm{L}$ to $20 \mathrm{mg} / \mathrm{L}$ show decrease from $0.516 \mathrm{mg} / \mathrm{L}$ to $0.252 \mathrm{mg} / \mathrm{L}$ or from $3.371 \%$ to $52.809 \%$. After 72 hours, iron concentration of tap water is $0.819 \mathrm{mg} / \mathrm{L}$. Findings of calcium hydroxide injection from $5 \mathrm{mg} / \mathrm{L}$ to $20 \mathrm{mg} / \mathrm{L}$ show decrease from $0.746 \mathrm{mg} / \mathrm{L}$ to $0.287 \mathrm{mg} / \mathrm{L}$ or from $8.913 \%$ to $64.957 \%$.

The findings suggest calcium hydroxide is highly effective in control of iron corrosion.

In addition, LI of -0.71 of the sample with $50 \mathrm{mg} / \mathrm{L}$ calcium hydroxide injection is good enough when LI of control group tap water -1.24 is compared to iron concentration, showing a 
decrease, suggesting that corrosion is suppressed in state of unsaturated calcium carbonate as shown in [Fig. 2].

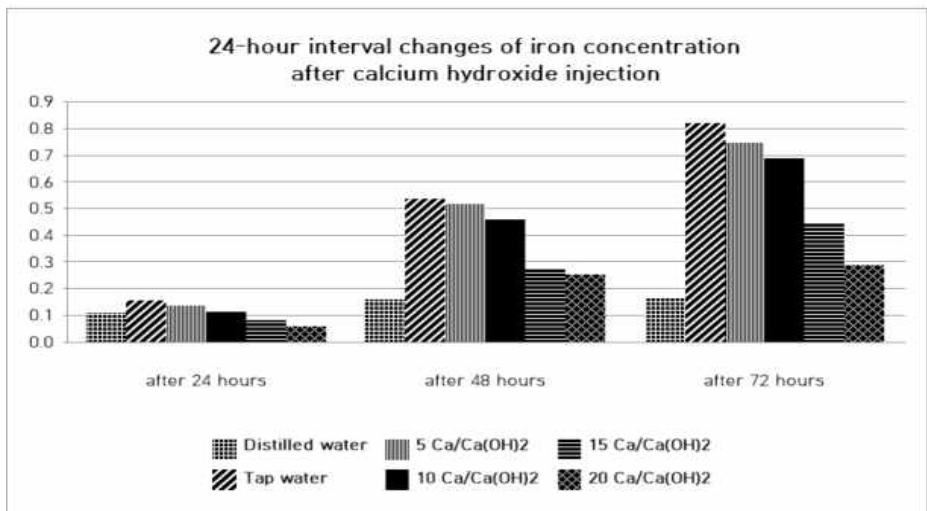

[Fig. 2] 24-hour Interval Changes in Iron Concentration in Response to Amount of Calcium Hydroxide Injection

\section{Summary and Conclusion}

This study suggested that animal farming disinfection, water supply in the farm and exposure of farm grounds disrupt improvement of animal immune system and analyzed the importance of livestock breeding environment management in preventing outbreak of diseases like infections. The findings are as follows:

1) After disinfecting the experimental with calcium hydroxide continuously for 5 weeks, initial resistance of microorganisms of spore-forming bacterias such as Anthrax bacterium, Clostridium chauvoei, Clostridium tetani, Clostridium septicum was $4.3 \mathrm{CFU}$. As a result of continuously disinfecting the farm from week 2, the resistance decreased from 4 CFU to 1.2 CFU.

2) In microbes with average resistance such as Mycobacterium tuberculosis, Staphylococcus, Streptococcus, resistance of microorganisms decreased from $4.8 \mathrm{CFU}$ in week 1 to $0.5 \mathrm{CFU}$ in week 5. In weak microbe category that includes Escherichia coli, Erysipelothrix rhusiopathiae, Foot-and-mouth disease virus, Swine fever virus, Newcastle disease virus, Rabies virus, Japanese encephalitis virus, it decreased from $3.9 \mathrm{CFU}$ in week 1 to $0.2 \mathrm{CFU}$ in week 5. Other various harmful microorganisms were almost eradicated in week 5 .

3) Corrosive index was measured lower in winter due to the influence of water temperature level which suggested that corrosion is more apparent in winter. Corrosion occurs easily in winter than summer with high temperatures. LI of -0.71 of sample with $50 \mathrm{mg} / \mathrm{L}$ calcium hydroxide injection is good enough when LI of control group tap water -1.24 is compared to 
iron concentration, which shows a decrease.

4) When calcium hydroxide for animal farming purpose is diluted in regular basis or in stages for corrosion experiment, the most appropriate amount of injection of calcium hydroxide is $15 \mathrm{mg} / \mathrm{L}$, alkalinity in response to injection concentration is $67 \mathrm{mg} \mathrm{CaCO} / \mathrm{L}$, and $\mathrm{pH}$ is 7.8 .

5) The study points out that more in-depth research is required as preventive intervention on contagious infections like swine fever which has become national disaster recently, and the findings suggest that continuous research in the use of calcium hydroxide is necessary in order to eradicate and prevent various strains of pathogens in the farm.

\section{Acknowledgement}

This is a joint research of Korea Economic Policy Institute of K-1 industrial corporation in Haman county, Gyeongnam province and School of National Resources and Life Science of Pusan National University.

\section{References}

[1] Ryu il Sun, Disinfection and prevention methods for controlling foot and mouth disease and infectious diseases, Korea Veterinary Medical Association, (2010), Vol.402, No.9, p.408.

[2] Wi Yeon Soo, A study on control of corrosion index factor by liquid slaked lime, Seoul National University of Science and Technology, Master Thesis, (2017)

[3] Ryu il Sun, Disinfection and prevention methods for controlling foot and mouth disease and infectious diseases, Korea Veterinary Medical Association, (2010), Vol.402, No.9, pp.402-412.

[4] W. S. Jeong, J. K. Kim, D. J. Park, S. W. Kim, S. K. Jeong, AA study on the corrosion control of tap water by lime and carbon dioxide, Journal of Korean Society of Water and Wastewater, (2011), Vol.25, No.2, pp.193-199.

[5] Kawamura, S., Integrated Design and Operation of Water Treatment Facilities, John Wiley \& Sons, (2014)

[6] http://www.ksvs.or.kr, Dec 10 (2019)

[7] http://www.mhlw.go.jp/, Mar 3 (2014)

[8] Choi Yeon Ho, Sludge solidification and stabilization using dregs of Waste from Milky Lime, Daejeon Bae jea University, Master Thesis, (2014)

[9] The National Institute of Technology and Standards Water quality - selection by induction coupled plasma atomic luminescence spectroscopy (ICP-OES), Element measurement method'KS I ISO 11885, (2013) 